\title{
Я.М. Кусий \\ ОПТИМІЗАЦІЯ МАРШРУТУ ОБРОБЛЕННЯ ПОВЕРХОНЬ ЗАГОТОВКИ ЗА КРИТЕРІЄМ ОДНОРІДНОСТІ СТРУКТУРИ МАТЕРІАЛУ
}

Анотація. Проаналізовано взаємозв'язки технологічного забезпечення життєвих циклів машинобудівних виробів. Описано методику вибору маршруту оброблення поверхонь деталей машин для об'єктно-орієнтованих технологічних процесів за критерієм розрахункового уточнення. Визначено множину відправних характеристик якості виробу для визначення граничного параметра технологічної операції для його функціональних поверхонь. Відзначено складнощі врахування експлуатаційних характеристик на різних рівнях досліджень при розробленні об'єктно-орієнтованих технологічних процесів. Обгрунтовано доцільність розроблення функціонально-орієнтованих технологій машинобудівного виробництва з позиції технологічного успадковування властивостей деталей машин. Представлено метод LM-твердості, що застосовується для вибору раціонального маршруту оброблення функціональних поверхонь виробу. Описано технологічне забезпечення реалізації експериментальних досліджень. Проаналізовано результати експериментальних досліджень та встановлено раціональний варіант маршруту оброблення плоскої заготовки із алюмінієвого сплаву. Намічено шляхи подальших досліджень.

Ключові слова: технологічний маршрут, життєвий цикл виробу, об'єктно-орієнтований технологічний процес, функціонально-орієнтований технологічний процес, технологічне успадковування, пошкоджуваність, заготовка, метод LM-твердості, гомогенність, коефіцієнт гомогенності Вейбулла

Постановка проблеми. Для сучасного машинобудування працемісткість механічного оброблення знижується за рахунок максимального наближення форм заготовок до форм деталей, зростання рівня механізації та автоматизації технологічних процесів (ТП), ступеня оснащеності та довговічності технологічного обладнання, інтенсифікації режимів оброблення, проте зростає при жорсткіших вимогах до точності оброблення, мікротопології поверхні виробів, їх експлуатаційних характеристик і показників надійності [1-2].

Фактор часу $\epsilon$ універсальною одиницею контролю технологічних параметрів виробів, що визначають їх ресурс [3]. Фактичний ресурс узгоджується з раціональним терміном служби виробу для оптимізації сумар-

(C) Кусий Я.М., 2021 


\section{«Системні технологіï» 1 (132) 2021 «System technologies»}

них витрат стосовно забезпечення працездатності на важливих етапах і стадіях його життєвого циклу [1-3].

Технологічне забезпечення ресурсу виробу пов'язане із конструкторськотехнологічною підготовкою виробництва (раціональний вибір конструктивних схем і матеріалів, досконалість розрахунків із врахуванням усіх впливів під час експлуатації деталей і машин, оптимізація режимів оброблення на сучасних металорізальних верстатах із застосуванням прогресивного інструменту) та його виготовленням (ретельний контроль матеріалів комплектуючих, високий рівень організації та контролю ТП виготовлення деталей і складання машин, належні випробування окремих елементів, вузлів і агрегатів тощо). Усунення технологічних дефектів при випробуваннях, дотримання термінів технічного обслуговування та ремонтів мінімізують виникнення відмов на стадії експлуатації виробів [3, 4].

Технологічне забезпечення регламентованих параметрів якості машинобудівних виробів потрібно здійснювати для усіх ланок технологічного ланцюжка заготовка-деталь за допомогою критеріїв комплексної оцінки деградації матеріалу виробу [5, 6].

Аналіз останніх досліджень і публікацій. Для об'єктно-орієнтованих технологічних процесів раціональна структура маршруту оброблення виконавчої поверхні виробу забезпечується множиною методів оброблення із дотриманням регламентованих вимог до точності та якості поверхневого шару при мінімальній технологічній собівартості. Методи оброблення вибирають з урахуванням способу отримання, габаритних розмірів та точності заготовки, властивостей матеріалу, технічного стану технологічного обладнання тощо. Об’єктно-орієнтований технологічний процес формується із сукупності технологічних маршрутів оброблення виконавчих поверхонь деталі [7].

у практиці машинобудування застосовують два варіанти вибору раціонального маршруту оброблення поверхонь виробу [8].

Перший варіант базується на забезпеченні технічних вимог щодо точності та якості виконавчих поверхонь із використанням типових планів їх обробки. Такий спосіб вибору маршруту оброблення виконавчих поверхонь $є$ укрупненим, вимагає високої кваліфікації технолога та не враховує умови подальшої експлуатації для конкретного виробу [8].

Розрахунковий метод визначення маршруту оброблення поверхонь грунтується на обчисленні загального уточнення $\varepsilon$. Можливі методи оброблення поверхонь встановлюють за коефіцієнтом уточнення $\varepsilon_{y i}$ [8]: 
«Системні технології» 1 (132) 2021 «System technologies»

$$
\varepsilon_{y i}=\left[T O p_{i-1}\right] /\left[T O p_{i}\right] \text {, }
$$

де $\left[T O p_{i-1}\right],\left[T O p_{i}\right]$ - значення лімітуючого параметра технологічної операції для визначеної функціональної поверхні виробу відповідно на попередньому та поточному технологічному переході.

Визначена $i$-та функціональна поверхня виробу $F S_{i}$ визначається множиною параметрів якості: точністю оброблення, геометричними (відхиленнями форми та взаємного розташування поверхонь, хвилястістю, показниками шорсткості та субмікрошорсткості) і фізико-механічними параметрами якості поверхневого шару:

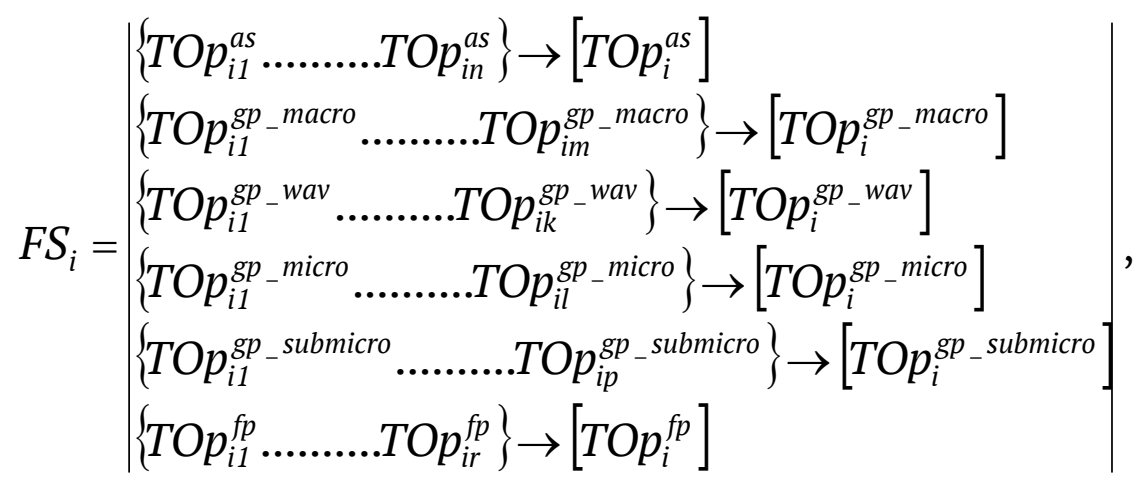

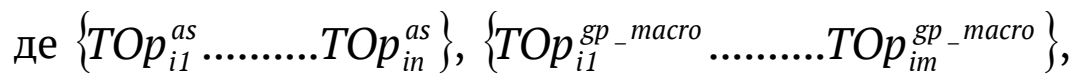

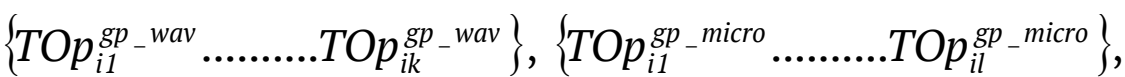
$\left\{T O p_{i 1}^{g p_{-}}\right.$submicro.........$T O p_{i p}^{g p_{-}}$submicro $\},\left\{T O p_{i 1}^{f p} \ldots . . . . . . T O p_{i r}^{f p}\right\}-$ сукупність відповідно $n$ параметрів точності, $m$ параметрів відхилення форми та взаємного розташування поверхонь, $k$ параметрів хвилястості, $l$ параметрів шорсткості, $p$ параметрів субмікрошорсткості, $r$ фізико-механічних параметрів якості поверхневого шару, що забезпечуються для $i$-тої функціональної поверхні; $\left.\left.\left[T O p_{i}^{a s}\right],\left[T O p_{i}^{g p_{-} m a c r o}\right],\left[T O p_{i}^{g p_{-} w a v}\right],\left\lfloor T O p_{i}^{g p_{-} \text {micro }}\right], \mid T O p_{i}^{g p_{-} \text {submicro }}\right\rfloor, \mid T O p_{i}^{f p}\right\rfloor-$ граничні (лімітуючі) значення відповідно показників точності, відхилення форми та взаємного розташування поверхонь, хвилястості, шорсткості, субмікрошорсткості, фізико-механічних параметрів якості поверхні.

Значення граничного параметра технологічної операції для визначеної функціональної поверхні виробу вибирають із сукупності лімітуючих значень параметрів якості:

$$
\begin{aligned}
& \left.\left[T O p_{i}^{a s}\right],\left[T O p_{i}^{g p_{-} m a c r o}\right],\left[T O p_{i}^{g p_{-} w a v}\right], \mid T O p_{i}^{g p_{-} \text {micro }}\right\rfloor, \\
& {\left[T O p_{i}^{g p_{-} \text {submicro }}\right],\left[T O p_{i}^{f p}\right] \rightarrow\left[T O p_{i}\right]}
\end{aligned}
$$




\section{«Системні технологіï» 1 (132) 2021 «System technologies»}

У машинобудівній практиці найчастіше критеріями оцінки розрахункового уточнення є забезпечувана точність оброблення або шорсткість обробленої виконавчої поверхні [8]:

$$
\begin{aligned}
& \varepsilon_{y i}=T_{i-1} / T_{i}, \\
& \varepsilon_{y i}=R a(R z)_{i-1} / R a(R z)_{i},
\end{aligned}
$$

де $T_{i-1}, R a(R z)_{i-1}$ - відповідно допуск забезпечуваного розміру та параметри шорсткості поверхні $R a$ або $R z$ на попередньому технологічному переході; $T_{i}$, $R a(R z)_{i}$ - відповідно допуск забезпечуваного розміру та параметри шорсткості поверхні $R a$ або $R z$ на поточному технологічному переході.

Кількість методів технологічних обробок $m$ розраховують за формулою [8]:

$$
m=\ell g\left(\varepsilon_{p}\right) / 0.46
$$

де $\varepsilon_{p}$ - розрахункове уточнення.

Розрахункове уточнення $\varepsilon_{p}$ обчислюють залежно від граничного критерію за формулами [8]:

$$
\begin{aligned}
& \varepsilon_{p}=T_{\text {заг. }} / T_{\text {дет. }}, \\
& \varepsilon_{p}=R a(R z)_{\text {заг. }} / R a(R z)_{\text {дет. }},
\end{aligned}
$$

де $T_{\text {заг., }} R a(R z)_{\text {заг. }}$ - відповідно допуск і шорсткість поверхні заготовки за параметром $R a(R z) ; T_{\text {дет. }} R a(R z)_{\text {дет. }}$ - відповідно допуск і шорсткість поверхні деталі за параметром $R a(R z)$.

Проте визначена кількість методів обробки функціональної поверхні виробу раціонально забезпечуватиме регламентовані параметри його якості за умови врахування на важливих етапах його життєвого циклу технологічного успадковування властивостей матеріалу у технологічному маршруті оброблення.

Великим недоліком проектування об'єктно-орієнтованих технологічних процесів виготовлення виробів є складність врахування в них експлуатаційних характеристик на різних рівнях досліджень [6, 7]. На етапі конструкторськотехнологічної підготовки машинобудівного виробництва реалізовують множину почергових взаємопов'язаних етапів структурно-параметричного синтезу на основі алгоритму прототипування [7]. 3 огляду на функціональні обов'язки конструктора технолог не може ефективно забезпечити необхідні експлуатаційні характеристики деталей зокрема і машин загалом у структурі технологічних процесів механічного оброблення та складання. Традиційні технологічні процеси виготовлення деталей та складання машин забезпечують, як правило, відповідно до технічних умов параметри якості поверхневого шару 


\section{«Системні технології» 1 (132) 2021 «System technologies»}

та вимоги до точності без їх взаємозв’язку із експлуатаційними властивостями машини загалом або її деталей зокрема. Однак адаптування машини або її деталей до реальних умов експлуатації супроводжується підвищенням виробничих витрат, що суперечить пріоритетним критеріям об’єктно-орієнтованих технологій - технологічній собівартості та максимальній продуктивності [6, 7].

Для певної групи виробів $\epsilon$ особливо важливим забезпечення експлуатаційних характеристик їх функціональних поверхонь 3 огляду на катастрофічні наслідки їх відмов в процесі експлуатації. Тому системний принцип забезпечення життєвого циклу таких деталей і машин вимагає врахування на етапі технологічної підготовки виробництва відповідно до експлуатаційних умов показники зносостійкості, втомної міцності тощо. Неспроможність реалізації потенціалу технолога у розробленні нового продукту та суттєве обмеження функцій конструкторсько-технологічної підготовки виробництва визначається опосередкованістю зв'язку етапів життєвого циклу виробу на підставі граничних умов [5-7].

Тому розроблення функціонально-орієнтованих технологій виготовлення виробів є важливим напрямком розвитку машинобудівного виробництва. Для прогресивних технологій виробничі впливи топологічно точно орієнтовані 3 необхідними параметрами тільки на функціонально-орієнтовані при експлуатації зони виробів, що забезпечуються на етапах і стадіях життєвих циклів деталей і машин [6, 7]. Поряд з тим [5, 6] технологічне успадковування властивостей матеріалу разом із впливами технологічного середовища необхідно враховувати при формуванні функціональних параметрів виробу відповідно до умов його подальшої експлуатації.

Мета дослідження. Метою даного дослідження є розроблення раціональних технологічних маршрутів оброблення функціональних поверхонь виробу 3 позиції технологічного успадковування його властивостей при проектуванні прогресивних технологій.

Викладення основного матеріалу дослідження. Технологічне забезпечення регламентованих параметрів якості машинобудівних виробів вимагає грунтовного аналізу причинно-успадкованих зв'язків, що описують еволюцію технологічного ланцюга відправна заготовка-готовий виріб. Необхідні експлуатаційні характеристики та прогнозований ресурс деталей машин залежить в першу чергу від умов формування властивостей їх матеріалу протягом стадії створення життєвих циклів виробів [9]. 


\section{«Системні технологіï» 1 (132) 2021 «System technologies»}

У машинобудівному виробництві виготовлення виробів здійснюється почерговим обробленням заготовок в умовах технологічних процесів металургійного, механічного, зварювального і механоскладального виробництв та технічного контролю $[1-4,9]$.

Кожний технологічний перехід, операція тощо вносить певні корективи не лише у формування властивостей матеріалу виробів і забезпечення точності їх оброблення та параметрів поверхневого шару, а й у зародження і розвиток технологічних дефектів, що можуть при несприятливих експлуатаційних умовах перероджуватися у технологічні пошкодження та спричиняти відмову деталей і машин [5, 6].

Відсутність узагальненого підходу до проектування раціональної структури технологічних процесів з урахуванням принципу технологічного успадковування властивостей виробу для забезпечення його експлуатаційних характеристик при дотриманні вимог конструкторсько-технологічної документації вимагає вдосконалення традиційних і розроблення нових технологічних процесів, зокрема функціонально-орієнтованих. Під функціональноорієнтованою технологією розуміють технологічний процес, спрямований на забезпечення найефективніших експлуатаційних характеристик виробу із дотриманням призначених конструктором параметрів точності та якості поверхневого шару виробу [7]. Вирішення поставленого завдання можливе за рахунок як детального аналізу технологічного ланцюга відправна заготовка - готовий виріб з позиції технологічного успадковування властивостей, так і застосування автоматизованого керування виробничими процесами із використанням SADT-технологій [9]. При впровадженні функціонально-орієнтованих технологій інтенсифікуються роботи конструкторсько-технологічної підготовки виробництва на забезпечення максимального позитивного результату у ланцюгу замовник-виробник [7].

Сформовані на стадії створення виробу дефекти структури у машинобудівних матеріалах при несприятливих експлуатаційних умовах можуть перетворитися у технологічні пошкодження, які можна прогнозувати за допомогою математичного апарату механіки руйнування та механіки пошкоджуваного середовища $[5,6]$.

Під пошкоджуваністю розуміють процес різко вираженої та нерівномірної зміни геометричного стану поверхонь тертя, структури і властивостей поверхневих шарів. Пошкодження формується внаслідок результуючого деградуючого впливу пошкоджуваності, що проявляється у зміні структури, властивостей, 
«Системні технології» 1 (132) 2021 «System technologies»

макрогеометричних характеристик і напруженого стану поверхневих шарів виробу під час його експлуатації [11].

Для механіки пошкоджуваного середовища справедлива математична залежність [12]:

$$
\tilde{M}=M /\left(1-D_{M}\right),
$$

де $M, \tilde{M}$ - відповідно величини істинної та ефективної властивостей оброблюваного матеріалу виробу; $D_{M}-$ кінетика накопичення пошкоджень (пошкоджуваність) для заданої властивості матеріалу деталі.

Встановлено [3, 4], що важливими параметрами вичерпання ресурсу матеріалу є процеси накопичення пошкоджень та деградації його фізикомеханічних властивостей для характерних видів руйнування: на відрив $-E$ та зріз - G. Параметром для аналізу еволюції деградації матеріалу для визначених умов експлуатації $є$ пошкоджуваність матеріалу при осьовому навантаженні $D_{\sigma}$ та при зсуві $-D_{\tau}[12]$ :

$$
\begin{aligned}
& D_{\sigma}=1-\sqrt{\frac{\widetilde{E}_{i}}{E_{0}}}, \\
& D_{\tau}=1-\sqrt{\frac{\tilde{G}_{i}}{G_{0}}} .
\end{aligned}
$$

Використання математичних залежностей (10), (11) у машинобудівній практиці вимагає спеціального вартісного обладнання та висококваліфікованого персоналу для забезпечення експериментальних досліджень, тому є складно реалізованим на підприємстві.

Поточний стан технологічної системи залежить від попереднього i визначається процесами успадковування властивостей, що описується диференційними рівняннями виду [13]:

$$
\begin{aligned}
\varphi^{(\gamma)} & {\left[O^{(\gamma)}(t), O^{(\gamma)}(t-\tau) ; \frac{d O^{(\gamma)}(t-\tau)}{d t} \ldots . .,\right.} \\
& \frac{d^{i} O^{(\gamma)}(t-\tau)}{d t^{i}}, \ldots . ., \frac{d^{n} O^{(\gamma)}(t-\tau)}{d t^{n}}, \ldots ., \\
& \left.\int_{t_{1}}^{t} O^{(\gamma)}(\xi) d G_{1}^{(\gamma)}(\xi, t), \ldots . . \int_{t_{k}}^{t} O^{(\gamma)}(\xi) d G_{k}^{(\gamma)}(\xi, t)\right]
\end{aligned}
$$

де $\varphi^{(\gamma)}, G_{k}^{(\gamma)}$ - деякі функції; $S_{F}=\left\{O^{(1)}(t), O^{(2)}(t), \ldots, O^{(\gamma)}(t)\right\}-$ функціональний опис системи; $O^{(l)}=O^{(l)}(b, c, d . . . .)-$. виходи системи; $(b, c, d . . . .)-$. ïï входи. 


\section{«Системні технологіï» 1 (132) 2021 «System technologies»}

Загальні закони організації та розвитку систем в межах синергетичного підходу підлягають системному функціонально-морфологічноінформаційному аналізу, на підставі дослідження взаємозв'язків і взаємовпливів функціонального, морфологічного та інформаційного опису $[13,14]$.

Функціональні процеси у системі безпосередньо пов'язані із інформаційними, при цьому джерелом інформації для їі функціонування $є$ внутрішній ресурс i середовище, а носієм - речовина (морфологічна інформація) та енергія. Внутрішня енергія характеризує еволюцію, цілі та діяльність системи $[13,14]$.

В рамках синергетичного підходу для опису технологічного успадковування властивостей виробів на етапах i стадіях їх життєвих циклів визначається обмежена кількість алгоритмів їх функціонування для автоматизованого забезпечення експлуатаційних характеристик і регламентованих параметрів якості продукту $[9,15]$. Це зумовлює вибір узагальнених критеріїв оцінки деградації властивостей матеріалу для аналізу технологічних параметрів при виготовленні деталей машин.

Моніторинг технічного стану елементів парових турбін за залишковим ресурсом із обов'язковим розрахунком конструкції за допустимими напруженнями здійснено у [16].

Авторами [16] скоректовано відомі постулати та запропоновано простішу та надійну, на їх погляд, методику визначення коефіцієнта запасу за граничним рівнем пошкоджуваності матеріалу. Однак у зв'язку із відсутністю достовірних математичних моделей, що описують кінетику накопичення пошкоджень і ї граничних значень, вони змушені були обмежитися визначенням коефіцієнтів запасу за сумарним граничним пошкодженням при повзучості (за часом до руйнування) і малоцикловій втомі (за кількістю циклів), використовуючи при цьому лінійне сумування пошкоджень.

Відомо, що рівень експлуатаційної напруженості деталей і конструкцій більшості машин обмежується коефіцієнтами безпеки, значення яких жорстко регламентуються. Зокрема значення коефіцієнтів безпеки для апаратури під тиском за границею текучості - 1.5-1.65; за границею міцності - 2.35-4.00. Очевидно, що рівень розрахункових напружень в 1.5 і більше разів нижче границі текучості [17].

Границі зерен, як нерівноважні дефекти, є місцем початку реалізації основних механізмів еволюції процесів деградації матеріалу [16]. Залежно від 


\section{«Системні технології» 1 (132) 2021 «System technologies»}

відправної структури матеріалу, зокрема, розмірів зерен і умов навантаження, вклад зсувів по поверхні границь зерен, біля граничних і внутрішньо зеренних деформацій може змінюватися від 1 до 90 \% повної деформації [17].

Цей факт дозволяє надати параметру пошкоджуваності конкретний фізичний зміст у вигляді відношення суми довжин пошкоджуваних границь зерен до довжини всіх границь у тому ж об’ємі матеріалу, а при одноосному розтягу (стиску) - до одиниці площі поперечного перерізу [18].

Способи оцінки ступеня пошкоджуваності матеріалу в умовах експлуатації за результатами прямих і непрямих вимірювань описано у [19, 20]. До числа найрезультативніших з неруйнівних методів відносять різновиди методу акустичної емісії та метод твердості.

На жаль, інформативні акустичні методи вимагають вартісного спеціального технічного забезпечення і складної процедури опрацювання результатів вимірювань, а метод твердості характеризується недостатньою інформативністю і низькою точністю, оскільки кореляція між значенням твердості матеріалу та його пошкоджуваністю у більшості випадків слабка і не завжди однозначна.

В зв’язку з цим, для обгрунтування вибору раціонального маршруту оброблення функціональних поверхонь виробу доцільно застосувати метод LMтвердості, розроблений під керівництвом академіка А.А. Лєбєдєва [17]. Цей метод фізично обгрунтований і експериментально підтверджений при напрацюваннях в умовах короткотривалого та довготривалого навантаження [5, 6]. Згідно методу LM-твердості, деградаційні процеси у матеріалі в умовах експлуатації можна оцінювати за ступенем розсіювання механічних властивостей матеріалу, зокрема твердості, визначення якої у будь-якому об’ємі випробувань здійснюється без руйнування виробу на стандартному обладнанні [17].

Гомогенність, що оцінюється за коефіцієнтом Вейбулла $(m)$, служить параметром для інтегральної характеристики стану матеріалу під час опрацювання результатів вимірювань твердості $[5,6,17]$ :

$$
m=d(n) /(2.30259 \cdot S(\lg (H))),
$$

де $d(n)$ - параметр, що визначається кількістю вимірювань n;

$$
\begin{aligned}
& S(\ell g(H))=\sqrt{\frac{1}{n-1} \cdot \sum_{i=1}^{n}\left(\ell g\left(H_{i}\right)-\overline{\ell g(H)}\right)^{2}}, \\
& \overline{\ell g(H)}=\frac{1}{n} \cdot \sum_{i=1}^{n} \lg \left(H_{i}\right) .
\end{aligned}
$$


«Системні технології» 1 (132) 2021 «System technologies»

Оцінку деградації властивостей матеріалу виробу можна здійснювати також за коефіцієнтом варіації [17]:

$$
v=(1 / \bar{H}) \cdot\left(1 / \sqrt{\frac{1}{n-1} \cdot \sum_{i=1}^{n}\left(H_{i}-\bar{H}\right)^{2}}\right),
$$

де $\bar{H}$ - середнє значення твердості.

Результати роботи та їх обгрунтування. Для експериментальних досліджень використали заготовку із алюмінієвого сплаву АК21M2.5Н2.5 ГОСТ 1853-93 з габаритними розмірами 165х155х22 мм, відлиту у піщану форму. Із відправної заготовки пилою відрізано зразок для досліджень в розмір 22x155x22 мм. Для базування на координатний кут профрезеровано однократно три взаємно перпендикулярні сторони на вертикально-фрезерному верстаті кінцевою фрезою Ø 30 мм.

Верхню необроблену поверхню заготовки фрезерували почергово на універсально-фрезерному верстаті мод. 676 кінцевою фрезою $\varnothing 12$ мм (z=2) за двома альтернативними технологічними маршрутами: заготовка - чорнове фрезерування - напівчистове фрезерування та заготовка - напівчистове фрезерування - чистове фрезерування. Режими різання: при чорновому фрезеруванні - B=2 мм, $\mathrm{t}=12 \mathrm{~mm}, \mathrm{~S}=255 \mathrm{~mm} / \mathrm{xB}, \mathrm{n}=515 \mathrm{xB}^{-1}$; при напівчистовому та чистовому фрезеруванні - B=2 мм, t=12 мм, $\mathrm{S}=13 \mathrm{Mm} / \mathrm{xB}, \mathrm{n}=1050 \mathrm{xB}^{-1}$.

Твердість заготовки вимірювали почергово після кожного оброблення на приладі ТР-5006 ГОСТ 23677-79 по шкалі Н за допомогою кульки Ø 3.175 при навантаженні $588.4 \mathrm{H}$ і кількістю вимірюваних значень для кожного досліду $n=30-35$ (рис. 1 ).

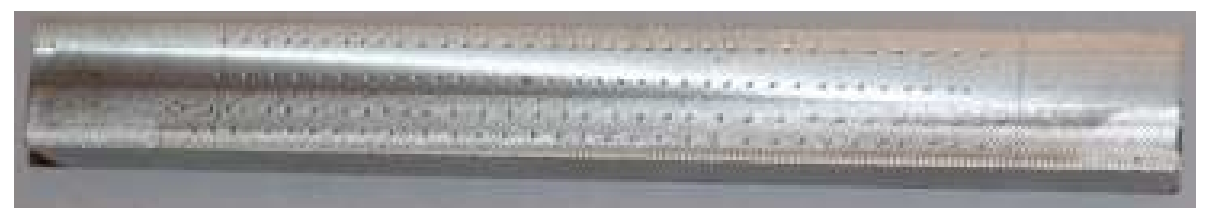

Рисунок 1 - Заготовка після фрезерування та вимірювання твердості контрольованих поверхонь

Статистичне опрацювання результатів експериментальних досліджень здійснювали за формулами (13)-(15) у середовищі Mathcad.

Результати експериментальних даних щодо вибору раціонального маршруту оброблення заготовки-виливка 3 алюмінієвого сплаву за критерієм пошкоджуваності - коефіцієнтом гомогенності Вейбулла $(m)$ для двох серій дослідів приведено на рис. 2 (незаштриховані прямокутники відповідають 
перерізам, ближчим до центру заготовки). Великим значенням коефіцієнта гомогенності Вейбулла $(m)$ відповідає низький рівень розсіювання характеристик твердості, тобто низький ступінь пошкоджуваності $D$; меншим значенням, навпаки, вищий рівень розсіювання характеристик твердості і вищий ступінь пошкоджуваності $D$.
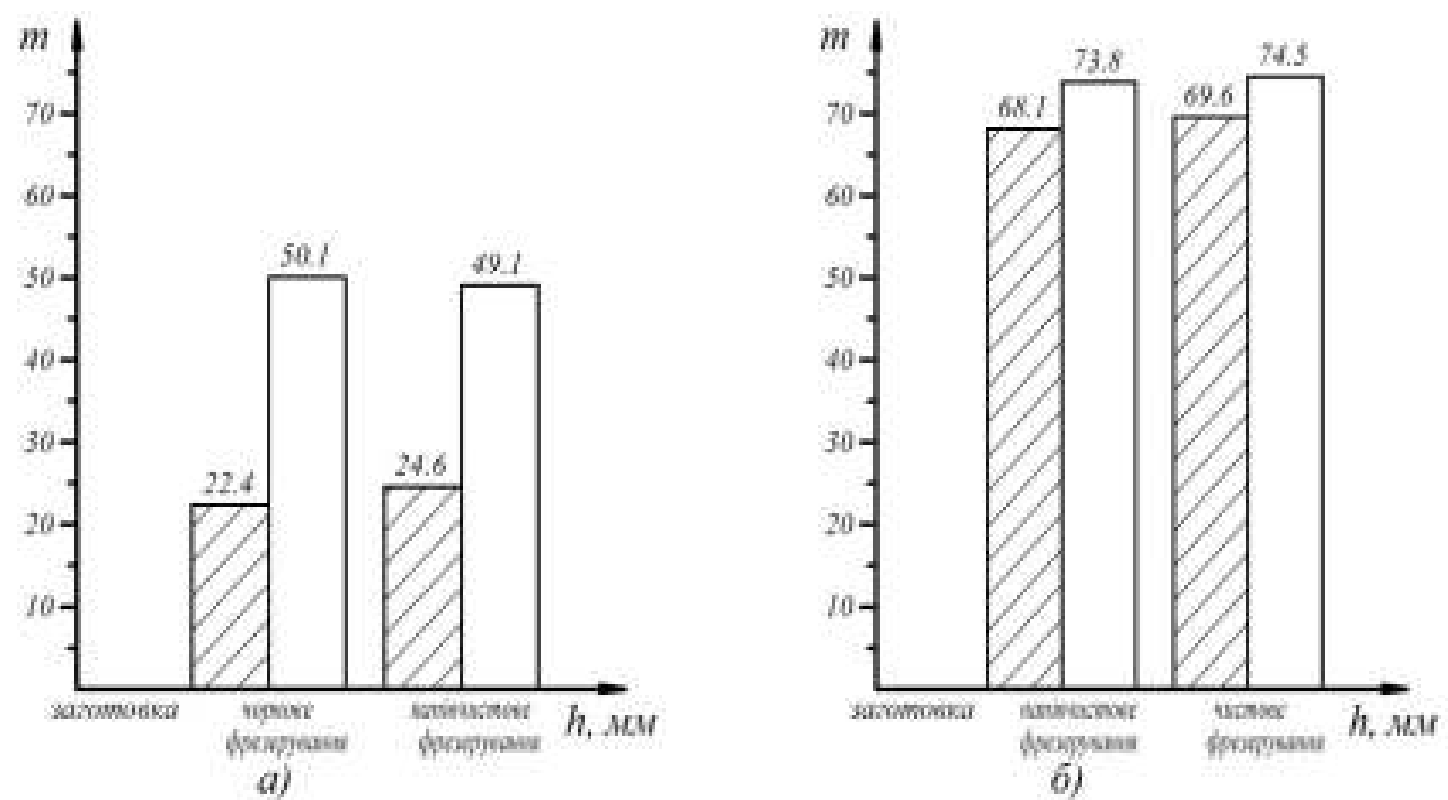

Рисунок 2 - Вибір раціонального маршруту оброблення плоскої поверхні виливка у землю з алюмінієвого сплаву за коефіцієнтом гомогенності Вейбулла (m)

Для першого варіанту технологічного маршруту (заготовка - чорнове фрезерування - напівчистове фрезерування) (рис. 2,a) після почергових обробок на глибини $\mathrm{h}_{1}=2 \mathrm{~mm} ; \mathrm{h}_{2}=4$ мм характерним $\epsilon$ високий рівень розсіювання характеристик для двох серій дослідів, що свідчить про більшу схильність до пошкоджуваності матеріалу у деформаційній зоні обробленого шару заготовки внаслідок інтенсифікації процесу різання на чорнових режимах.

Аналіз результатів, отриманих для другого варіанту технологічного маршруту (заготовка - напівчистове фрезерування - чистове фрезерування) (рис. $2, б)$ після почергового оброблення на глибини $\mathrm{h}_{1}=2 \mathrm{Mм} ; \mathrm{h}_{2}=4$ мм свідчить про загальну тенденцію до високої впорядкованості структури матеріалу з огляду на вищі значення коефіцієнтів гомогенності та їх незначні відхилення для двох серій дослідів порівняно з першим варіантом, що пов'язано із зменшенням технологічної пошкоджуваності матеріалу в зонах напівчистової і чистової фрезерної обробок. 


\section{«Системні технології» 1 (132) 2021 «System technologies»}

Інтенсифікація силових навантажень при чорновій механічній обробці сприяє отриманню в заготовках градієнтної структури, підвищенню рівня розсіювання механічних характеристик та зростанню пошкоджуваності поверхневих шарів. Зменшення силових впливів процесу різання на напівчистових i чистових режимах знижує кількість структурних концентраторів напружень, що підвищує рівень однорідності структури та зменшує ступінь пошкоджуваності поверхні.

На підставі аналізу отриманих результатів можна зробити висновок, що технологічний маршрут оброблення площини: заготовка - напівчистове фрезерування - чистове фрезерування буде пріоритетнішим за технологічний маршрут: заготовка - чорнове фрезерування - напівчистове фрезерування 3 огляду на вищі значення коефіцієнтів гомогенності Вейбулла $(m)$ та суттєво менше розсіювання виміряних значень твердості для двох серій дослідів. У той же час продуктивність оброблення згідно другого варіанту є у 19,6 разів нижчою, ніж для першого.

Висновки. Розроблено методику раціонального вибору маршруту обробки поверхонь деталей при проектуванні технологічних процесів за ступенем розсіювання вимірювань твердості матеріалу виробів для альтернативних варіантів. Вперше застосовано метод LM-твердості для аналізу ступеня пошкоджуваності матеріалу виробу при формуванні оптимального поєднання методів обробки різанням для забезпечення параметрів якості деталей. Подальші дослідження пов'язані з використанням розробленої методики вибору шляху обробки поверхні машинних виробів для більш широкого асортименту матеріалів та адаптації їі для сучасної машинобудівної галузі.

\section{ЛІТЕРАТУРА / ЛИТЕРАТУРА}

1. Проников А.С. Надежность машин - М. : Машиностроение, 1978. - 592 с.

2. Проников А.С. Параметрическая надежность машин / А.С. Проников. - М. : Изд.-во МГТУ им. Н.Э. Баумана, 2002. - 560 с.

3. Болотин В.В. Прогнозирование ресурса машин и конструкцій / В.В. Болотин. - М.: Машиностроение, 1984. - 312 с.

4. Болотин В.В. Ресурс машин и конструкций / В.В. Болотин. - М.: Машиностроение, 1990. - 448 с.

5. Kusyi Ya.M. Investigation of the technological damageability of castings at the stage of design and technological preparation of the machine Life Cycle / Ya.M. Kusyi, , A.M. Kuk // Journal of Physics: Conference Series. - 2020. - Volume 1426. https://iopscience.iop.org/article/10.1088/1742-6596/1426/1/012034/pdf.

doi:10.1088/1742-6596/1426/1/012034. 


\section{«Системні технологіï» 1 (132) 2021 «System technologies»}

6. Kusyi Ya., Stupnytskyy V. Optimization of the Technological Process Based on Analysis of Technological Damageability of Casting / Ya. Kusyi, V. Stupnytskyy // Advances in Design, Simulation and Manufacturing III. Proceedings of the 3rd International Conference on Design, Simulation, Manufacturing: The Innovation Exchange, DSMIE-2020, June 9-12, 2020, Kharkiv, Ukraine. - 2020. - Volume 1: Manufacturing and Materials Engineering. - P. 276-284.

7. Stupnytskyy V. Features of Functionally-Oriented Engineering Technologies in Concurrent Environment / V. Stupnytskyy // International Journal of Engineering Research \& Technology (IJERT). / - 2013. - Vol. 2, Issue 9. - P. 1181-1186.

8. Технологія машинобудування: Посібник-довідник для виконання кваліфікаційних робіт: навч. посібник / [Юрчишин I. І., Литвиняк Я. М., Грицай I. Є. та інші]; за ред. I. І. Юрчишина. - Львів: Видавництво Національного університету “Львівська політехніка”, 2009. - 528 с.

9. Технологические основы управления качеством машин / [Васильев А.С., Дальский А. М., Клименко С. А. и др.]. - М.: Машиностроение, 2003. - 256 с.

10. Кусий Я. М. Технологічне успадковування властивостей при забезпеченні параметрів якості виробу в процесі його виготовлення / Я. М. Кусий // Системні технології. - 2019. - Т.5 № 124. - С. 171-184.

11. Закалов О.В. Основи тертя і зношування в машинах: навчальний посібник / О.В. Закалов, І.О. Закалов.-Тернопіль: Видавництво ТНТУ ім. І.Пулюя,2011.322c.

12. Murakami S. Continuum Damage Mechanics - A Continuum Mechanics Approach to the Analysis of Damage and Fracture. / S. Murakami - Springer, Dordrecht, Heidelberg, London, New York, 2012. - 402 p.

13. Эбелинг В. Образование структур при необратимых процессах. Введение в теорию диссипативных структур / В. Эбелинг, пер. с нем. А. С. Доброславского. - М.: Мир, 1979.- 279 с.

14. Дружинин В.В., Конторов Д.С. Системотехника / В.В. Дружинин, Д.С. Конторов. - М.: Радио и связь, 1985. - 200 с.

15. Технологические и эксплуатационные методы обеспечения качества машин / [Альгин В. Б., Блюменштейн В. Ю., Васильев А. С. и др.]; под. общ. ред. П.А. Витязя. - Минск: Беларус. навука, 2010. - 109 с.

16. Обеспечение надежности и ресурса энергетических турбоагрегатов использованием системы диагностики вибраций и предупреждения нештатных ситуаций / Н.Г.Шульженко, Л.Д. Метелев, Ю.Г. Ефремов [и др.] // Энергетика и электрификация. - 2004.- № 5.- С. 41-43.

17. Лебедев А.А. Кинетика накопления рассеянных повреждений в поликристаллических материалах с разным размером зерна при малых деформаціях // А.А. Лебедев, В.П. Ламашевский, Н.Р. Музыка [и др.] - Проблемы прочности. 88 
«Системні технологіï» 1 (132) 2021 «System technologies»

2011.- № 5. - C. 32-44.

18. Арутюнян Р. Проблемы деформационного старения и длительного разрушения в механике материалов - СПб: Изд-во СПБ ун-та, 2004. - 252 с.

19. Дрозд М.С. Определение механических свойств металла без разрушения / М.С. Дрозд. - М: Металлургия, 1965. - 171 с.

20. Недосека А.Я. Основы расчета и диагностики сварных конструкций / Под ред. Б.Е. Патона. - К: Изд-во методической литературы и наглядных пособий, 1996. - 140 c.

\section{REFERENCES}

1. Pronikov A. S. Nadezhnost' mashin - M.: Mashinostroenie, 1978. - 592 p.

2. Pronikov A.S. Parametricheskaya nadezhnost' mashin / A.S. Pronikov. - M. : Izd.vo MGTU im. N.E. Baumana, 2002. - 560 s.

3. Bolotin V.V. Prognozirovanie resursa mashin i konstrukcij / V.V. Bolotin. - M.: Mashinostroenie, 1984. - $312 \mathrm{~s}$.

4. Bolotin V.V. Resurs mashin i konstrukcij - M.: Mashinostroenie, 1990. - 448 s.

5. Kusyi Ya.M. Investigation of the technological damageability of castings at the stage of design and technological preparation of the machine Life Cycle / Ya.M. Kusyi, , A.M. Kuk // Journal of Physics: Conference Series. - 2020. - Volume 1426. https://iopscience.iop.org/article/10.1088/1742-6596/1426/1/012034/pdf.

doi:10.1088/1742-6596/1426/1/012034.

6. Kusyi Ya., Stupnytskyy V. Optimization of the Technological Process Based on Analysis of Technological Damageability of Casting / Ya. Kusyi, V. Stupnytskyy // Advances in Design, Simulation and Manufacturing III. Proceedings of the 3rd International Conference on Design, Simulation, Manufacturing: The Innovation Exchange, DSMIE-2020, June 9-12, 2020, Kharkiv, Ukraine. - 2020. - Volume 1: Manufacturing and Materials Engineering. - P. 276-284.

7. Stupnytskyy V. Features of Functionally-Oriented Engineering Technologies in Concurrent Environment / V. Stupnytskyy // International Journal of Engineering Research \& Technology (IJERT). / - 2013. - Vol. 2, Issue 9. - P. 1181-1186.

8. Tekhnolohiia mashynobuduvannia: Posibnyk-dovidnyk dlia vykonannia kvalifikatsiinykh robit: navch. posibnyk / [Iurchyshyn I. I., Lytvyniak Ya. M., Hrytsai I.Ye.ta inshi]; za red. I.I. Yurchyshyna. - Lviv: Vydavnytstvo Natsionalnoho universytetu “Lvivska politekhnika”, 2009. - 528 s.

9. Tehnologicheskie osnovy upravleniia kachestvom mashin / [Vasil'ev A. S., Dal'skii A. M., Klimenko S. A. et al.]. - M.: Mashinostroenie, 2003. - 256 p.

10. Kusyi Ya. M. Tekhnolohichne uspadkovuvannia vlastyvostei pry zabezpechenni parametriv yakosti vyrobu v protsesi yoho vyhotovlennia / Ya. M. Kusyi // Systemni tekhnolohii. - 2019. - T.5 № 124. - S. 171-184.

11. Zakalov O.V. Osnovy tertia i znoshuvannia v mashynakh: navchalnyi posibnyk / 


\section{«Системні технології» 1 (132) 2021 «System technologies»}

O.V. Zakalov, I.O. Zakalov.-Ternopil: Vydavnytstvo TNTU im. I.Puliuia, 2011.-322 s. 12. Murakami S. Continuum Damage Mechanics - A Continuum Mechanics Approach to the Analysis of Damage and Fracture. / S. Murakami - Springer, Dordrecht, Heidelberg, London, New York, 2012. - 402 p.

13. Ebeling V. Obrazovanie struktur pri neobratimyh processah. Vvedenie v teoriyu dissipativnyh struktur / V. Ebeling, per. s nem. A. S. Dobroslavskogo. - M.: Mir, 1979.- 279 s.

14. Druzhinin V.V., Kontorov D.S. Sistemotekhnika / V.V. Druzhinin, D.S. Kontorov. - M.: Radio i svyaz', 1985. - 200 s.

15. Tekhnologicheskie i ekspluatacionnye metody obespecheniya kachestva mashin / [Al'gin V. B., Blyumenshtejn V. YU., Vasil'ev A. S. i dr.]; pod. obshch. red. P.A. Vityazya. - Minsk: Belarus. navuka, 2010. - 109 s.

16. Obespechenie nadezhnosti i resursa energeticheskih turboagregatov ispol'zovaniem sistemy diagnostiki vibracij i preduprezhdeniya neshtatnyh situacij / N.G.SHul'zhenko, L.D. Metelev, YU.G. Efremov [i dr.] // Energetika i elektrifikaciya. 2004. - № 5.- S. 41-43.

17. Lebedev A.A. Kinetika nakopleniya rasseyannyh povrezhdenij v polikristallicheskih materialah s raznym razmerom zerna pri malyh deformaciyah // A.A. Lebedev, V.P. Lamashevskij, N.R. Muzyka [i dr.] - Problemy prochnosti. 2011.- № 5. - S. 32-44.

18. Arutyunyan R. Problemy deformacionnogo stareniya i dlitel'nogo razrusheniya V mekhanike materialov / R. Arutyunyan. - SPb: Izd-vo SPB un-ta, 2004. - 252 s.

19. Drozd M.S. Opredelenie mekhanicheskih svojstv metalla bez razrusheniya / M.S. Drozd. - M: Metallurgiya, 1965. - $171 \mathrm{~s}$.

20. Nedoseka A.YA. Osnovy rascheta i diagnostiki svarnyh konstrukcij / Pod red. B.E. Patona. - K: Izd-vo metodicheskoj literatury i naglyadnyh posobij, 1996. - $140 \mathrm{~s}$.

\section{Оптимизация маршрута обработки поверхностей заготовки}

Received 18.01.2021. Accepted 19.01.2021. по критерию однородности структуры материала

Проанализированы взаимосвязи технологического обеспечения жизненных циклов машиностроительных изделий. Описана методика выбора маршрута обработки поверхностей деталей машин для объектно-ориентированных технологических процессов по критерию расчетного уточнения. Обоснована важность разработки функциональноориентированных технологий с позиции технологического наследования свойств деталей машин. Аргументирована актуальность исследования процессов накопления повреждений и деградации материала для характерных видов разрушения изделий. Обоснована целесообразность синергетического подхода при анализе технических объектов и технологических систем. Представлен метод LM-твердости, применяемый для выбора рационального маршрута обработки функциональных поверхностей изделия. Описано технологическое обеспечение реализации экспериментальных исследований. Проанализиро- 


\section{«Системні технологіï» 1 (132) 2021 «System technologies»}

ваны результаты экспериментальных исследований и выбран рациональный вариант маршрута обработки плоской заготовки из алюминиевого сплава. Намечены пути дальнейших исследований.

\section{Optimization of the technological route of blank surfaces using criterion of homogeneity of material structure}

The technological providing of the relationships between the resource of the mechanical engineering products and the characteristics of design and technological preparation of their Life Cycles is analyzed. The technique of selection of the surface treatment route of machine products is described for object-oriented technological processes using the criterion of design refinement. The set of initial characteristics of product quality to determine the limit parameter of the technological operation for its functional surface is determined. The problems to provide the performance characteristics at different levels of investigations during the development of object-oriented technological processes are argued. The goal of this research is development the technique of selection of the surfaces treatment route of machine products for technological processes planning. The expediency of developing of the functionally-oriented technologies from the position of technological inheritability of the machine parts properties is established. For modern technologies, production influences are topologically precisely oriented by means of the necessary parameters of products during their operational phase on functionally-oriented zones of product only. This is provided at the substages and stages of Life Cycles of Parts and Machines. The actuality of the study of the processes of damage accumulation and material degradation for the characteristic types of products destruction is argued. The expediency of a synergetic approach in the analysis of technical objects and technological systems is established. The $L M$-hardness method used to select a rational route for processing of the functional surfaces of the product have been considered. Technological support for the implementation of experimental researches is described. The results of experimental researches are analyzed. A rational variant of the route of processing a flat aluminum alloy blank is selected. Further research is related with using developed technique of selection of the surface treatment route of machine products for wider range of materials and adapting it for modern mechanical engineering industry.

Кусий Ярослав Маркіянович - к.т.н., доцент, докторант кафедри робототехніки та інтегрованих технологій машинобудування Національного університету «Львівська політехніка».

Кусый Ярослав Маркиянович - к.т.н., доцент, докторант кафедры робототехники и интегрированных технологий машиностроения Национального университета «Львовская политехника».

Kusyi Yaroslav - PhD, associate professor, Doctoral Candidate of the Department of Robotics and Integrated Mechanical Engineering Technologies of Lviv Polytechnic National University (Ukraine). 